\title{
THE EFFECT OF RELIGIOSITY, THE LEVEL OF INCOME, AND THE LEVEL OF ISLAMIC FINANCIAL LITERACY TOWARD THE INTEREST OF STUDENT TO BECOME CUSTOMERS IN SHARIA FINANCIAL INSTITUTION
}

\author{
(An empirical study on student of Faculty of Economics in Yogyakarta State \\ University and Sunan Kalijaga Yogyakarta State Islamic University) \\ Rifda Amalia Luthfiani \\ Program Studi Akuntansi Fakultas Ekonomi Universitas Negeri Yogyakarta \\ rifdaamalialuthfiani@gmail.com \\ Ratna Candra Sari \\ Staf pengajar Program Studi Akuntansi Universitas Negeri Yogyakarta \\ ratna_candrasari@uny.ac.id
}

\begin{abstract}
The Effect of Religiosity, The Level of Income, and The Level of Islamic Financial Literacy Toward The Interest Of Student To Become Customers In Sharia Financial Institution. This research aims to analyze (1) the effect of religiosity toward the interest of students to become customers in Sharia financial institutions, (2) the effect of income on the interest of students to become customers in Sharia financial institutions, (3) the effect of the level of Islamic financial literacy the interest of students to become customers in Sharia financial institutions, and (4) the effect of religiosity, income, and the level of Islamic financial literacy the interest of students to become customers in Sharia financial institutions.This research was causal research, used a purposive sampling method, and used multiple linear regression technique. The results of this research indicate that all independent variables have a positive effect on the dependent variable.
\end{abstract}

Keywords : The Interest of Students to Become Customers in Sharia Financial Institutions, Religiosity, The Level of Income, The Level of Islamic Financial Literacy

Abstrak : Pengaruh Religiusitas, Tingkat Pendapatan dan Tingkat Literasi Keuangan Syariah terhadap Minat Mahasiswa menjadi Nasabah pada Lembaga Keuangan Syariah. Penelitian ini bertujuan untuk mengetahui (1) pengaruh religiusitas terhadap minat mahasiswa menjadi nasabah pada lembaga keuangan syariah, (2) pengaruh tingkat pendapatan terhadap minat mahasiswa menjadi nasabah pada lembaga keuangan syariah, (3) pengaruh tingkat literasi keuangan syariah terhadap minat mahasiswa menjadi nasabah pada lembaga keuangan syariah, dan (4) pengaruh religiusitas, tingkat pendapatan, dan tingkat literasi keuangan syariah terhadap minat mahasiswa menjadi nasabah pada lembaga keuangan syariah. Penelitian ini adalah penelitian kausal, menggunakan metode purposive sampling dan menggunakan teknik analisis regresi linear berganda. Hasil dari penelitian ini menunjukkan bahwa semua variabel independen berpengaruh positif terhadap variabel depende.

Kata kunci : Minat Mahasiswa Menjadi Nasabah Pada Lembaga Keuangan Syariah, Religiusitas, Tingkat Pendapatan dan Tingkat Literasi Keuangan Syariah 


\section{PROBLEM BACKGROUND}

In 1992, Sharia Finacial Institutions in Indonesia began to develop marked by the establishment of Bank Muamalat Indonesia (BMI) initiated by the Indonesian Ulema Council (MUI) and the Government of Indonesia. The government then amended Law No. 7 of 1992 into Law No. 10 of 1998 stating that Conventional Banks may operate based on sharia principles by opening a Sharia Business Unit (UUS). The Indonesian government follows the steps of Malaysia which first implemented the dual banking system in 1983. In 2015, Dhani Gunawan Idat, Director of Research, Development, Arrangement, and Licensing of OJK Sharia Banking said that the total sharia banking customers were still smaller than the total conventional banking customers namely $15-20 \%$. This shows that the development of Sharia Finacial Institutions in Indonesia is still lagging behind, even though $85 \%$ of the population in Indonesia is Muslim (Badan Pusat Statistik, 2016).

The results of National Financial Literacy and Inclusion Survey 2016 shows that the Indonesian Islamic financial literacy index is at $8.1 \%$, the meaning is every 100 residents in Indonesia, only 8 are aware of the Islamic financial services industry. This fact is lower than the conventional financial literacy indexwhich is at $29.5 \%$, but when viewed from the sector, the Islamic banking literacy index shows the highest number compared to other sectors. The following is the Islamic Financial Literacy Index based on the financial services sector.

Research in Malaysia was conducted by Bley \& Kuehn (2004) and Hamid \&Nordin (2001) also shows that almost $100 \%$ of the Muslim population is aware of the existence of a Sharia Bank, but only $27.3 \%$ have completely gotten the difference between conventional banks and Islamic banks. The low intention to become a customer in sharia financial institutions is because Islamic banks are still classified as newcomers in this country and have not been able to complete the shortcomings in conventional institutions, besides academic activists need to provide education about Islamic financial literacy so that our society is literate sharia financial institutions (Lahsasna, 2016).

There are many factors that influence someone's interest to become customers in Sharia Finacial Institutions, especially Islamic banks. A person's interest in becoming a customer in Sharia Finacial Institutions can arise from within themselves or from the social environment. According to Crow in Rouf (2011), there are 3 main factors forming interest, namely factors from within a person, social motive 
factors, and emotional factors. The factor from within a person is the desire of someone who arises because of physical needs that must be met, if someone becomes a customer in a sharia financial institution because he needs and considers it important then he will do it. The social motive factor is the need to get recognition from the environment, if a person has an environment that is predominantly a customer of a sharia financial institution, that person will become a customer in a sharia financial institution to be accepted by his environment. Whereas emotional factors are related to feelings or emotions where activities carried out by someone bring more attention and feel happy. Inperson factors that influence someone's interest in becoming a customer in sharia financial institutions are supported by previous research which found that religious factors (religiosity) were the main factor in choosing Islamic banks (Hegazy, 1995; Metwally, 1996). Another factor that affects is income. According to Kotler (2009), consumer behavior is influenced by personal factors such as age, life cycle stage, lifestyle, and income. Income has an influence on a person's behavior in saving because saving is part of the income that is not consumed (Ernita, et. Al., 2013), so researchers suspect that if someone's income is high it will affect the amount of savings, and vice versa if someone's income is low savings are also low. In addition to religiosity and income, the level of Islamic finance literacy also affects a person to have a relationship with Islamic banks, this is supported by Abdullah and Anderson (2015).

Religiosity is devotion to religion. According to Glock \& Stark in Ancok (2011), said that there are five dimensions in religiosity, namely ideological, ritualistic, experimental, intellectual, and consequential dimensions. From the five dimensions will get a different level of religiosity. The emergence of Islamic banks as one of the products of Sharia Finacial Institutions is due to the strong encouragement of religious beliefs both textually and historically, where religion is believed to discuss life and worldly management issues including managing banks and how to transact (Antonio: 1999). The low level of religiosity causes the low interest of the community to become customers in Islamic banks, and vice versa. If someone has a high level of religiosity, that person will commit in carrying out the teachings of the religion they adhere to, including in economic activities. This is supported by the research of Yousseef $\&$ Kortam (2015) that religiosity has an impact on one's decision to become a customer in sharia financial institutions, 
especially Islamic banks. Thus religiosity should have a large role in the interest of the community to become customers in Sharia Finacial Institutions.

Another factor that affects someone to have a relationship with Islamic banks is the level of Islamic financial literacy. According to Huston(2010) explains that financial literacy includes awareness and knowledge of financial instruments and their applications in business and life so that Islamic financial literacy can be said as awareness and knowledge of financial instruments and their applications in business and life according to the teachings Islam. Based on research conducted by Abdullah \&Anderson (2015) and Purnomo \& Rosidah (2016), the level of Islamic finance literacy affects a person to have a relationship with Sharia Finacial Institutions, especially being a customer in Islamic banks. The research conducted by Herdianti (2018) also supported that the level of Islamic financial literacy influences a person to have a relationship with a sharia financial institution, the relationship in this case is to become a customer. The study used students to become research samples.

Students become one of the target targets in the Indonesian National Financial Literacy Strategy (SNLKI), with the hope that students can become good suppliers of information about Islamic financial literacy later. Students will be faced with economic choices, so students must have skills in managing their finances. According to research conducted by Abdullah \&Anderson (2015) and Ford \& Kent (2010), the level of Islamic financial literacy at the age of students is classified as low. This is also supported by research by Margareta\&Pambudhi (2015) which shows that the level of student financial literacy is $48.91 \%$ in the low category. Interest in becoming a customer in sharia financial institutions is one form of decision that can be taken by students, but there are still some obstacles that cause students not to use Islamic banks because each student has their own characteristics, such as differences in the level of religiosity, differences in income, and literacy level Islamic finance.

If students become one of the targets in the Indonesian National Financial Literacy Strategy (SNLKI), researchers are also interested in researching students as the object of this research by making Yogyakarta State University (UNY) and Sunan Kalijaga State Islamic University (UIN) as a place of research. Yogyakarta State University (UNY) and the State Islamic University (UIN) Sunan Kalijaga Yogyakarta are State Universities in Yogyakarta. However, the State Islamic University (UIN) of Sunan Kalijaga 
Yogyakarta is a religious-based university. This difference is then interesting to study and be associated with the aspects of religiosity and the level of Islamic finance literacy. There is a general perception that religious-based universities will have students with high levels of religious finance and literacy.

Based on the description of the background above, the researcher was interested in conducting research entitled "The Effect of Religiosity, The Level of Income, and Level of Islamic Financial Literacy Toward The Interest Of Student To Become Customers In Sharia Financial Institution"

\section{RESEARCH METHOD}

\section{Type of Research}

The types of research used in this research are causal-comparative research. Comparative causal research is a type of research that seeks to determine the cause and effect relationship between the dependent variables independently and test the existing hypothesis. The purpose of this study was to determine the effect of religiosity, the level of income, and the level of Islamic financial literacy on the interest of students to become customers in Sharia Finacial Institution. Based on the data used, this research is included in quantitative research, where this research is to test the hypothesis that has been set. The quantitative research method is a research approach that is based on the philosophy of positivism, which is a school of philosophy that states natural science as the only source of true knowledge, knows no speculation, and all are based on empirical data. Research data in the form of numbers and data analysis using statistics (Sugiyono, 2015).

\section{Place and Time Research}

This research will be conducted at Yogyakarta State University (UNY) and Sunan Kalijaga Yogyakarta State Islamic University (UIN). The time for conducting this research is September 2018 - February 2019.

\section{Research Subject}

The population in this research were S1 Economics students in UNY and UIN. The technique used in sampling in this study is by using a purposive sampling technique with several criteria and there are 193 students were collected in this research.

\section{Techniques and Instruments Data Collection}

The data used in this study are primary data. The technique used to collect data in this study uses an online questionnaire that is packed with Google form features. The questionnaire is a way of collecting data by giving a set of written questionnaires to respondents to answer 
(Sugiyono, 2015). The online questionnaire contains a statement regarding the religiosity, income, and level of Islamic financial literacy. A research instrument is a tool used to measure social and natural phenomena observed (Sugiyono, 2015). The research instrument used in this study was a closed questionnaire, so respondents only needed to provide a checklist $(\sqrt{ })$ on the alternative answers provided.

The measurement of each variable in this study uses a Likert scale with points 1 to 4 . The Likert scale is used to measure attitudes, opinions, and perceptions of a person or group of people about phenomena or social symptoms (Riduan \& Sunarto, 2009).

In the online questionnaire the interest of students to become customers in sharia financial institutions, this study uses a questionnaire developed by Lucas and Britt (2003) and has been used by Maghfiroh (2018), to measure the level of religiosity, using five dimensions revealed by Glock and Stark, which has been adapted from Yudhistira (2016), to measure the level of income, this study uses four dimensions that have been used in Maghfiroh (2018), while measuring the level of Islamic financial literacy using measurements proposed by Antara, et. Al., (2016).

\section{Validity and Reliability of Instruments}

Validity is a measure of an instrument that aims to test the validity of the instrument. A valid instrument means that the measuring instrument used to obtain data (measure) can be used to measure what should be measured (Sugiyono, 2015). To test the validity of the research instrument can use the SPSS version 20 with the product moment correlation technique from Pearson with the provision that if the value of $r$ count $>$ rtable value then the statement item is declared valid and if $r$ count $<r$ table, the measuring instrument is invalid. (Umar, 2011). Based on the calculation results, it is known that for the religiosity questionnaire there are 15 items of questions, there are 17 questions of Islamic financial literacy level questionnaire, and there are 10 items of interest in becoming customers in sharia financial institutions. After the validity test, there were 2 question items which were dropped from the religiosity questionnaire and 1 item was dropped from the interest questionnaire to become a customer in sharia financial institutions.

Instrument reliability testing shows the extent to which the instrument can provide consistent measurement results if measurements are made repeatedly. Measurement of reliability is measured using alpha Cronbach's formula, with SPSS 
version 20. Provisions for calculating the reliability of the instrument are as follows::

1. If $r$ count $>r$ table, then the measuring instrument is reliable

2. If $\mathrm{r}$ count $<\mathrm{r}$ table, then the measuring instrument is not reliable

Based on the results of the reliability test, the results obtained that the instrument of religiosity questionnaire, the level of Islamic financial literacy, and the interest of students to become customers in Sharia Finacial Institutions are reliable.

\section{RESULT AND DISCUSSION}

\section{Data Analysis Techniques}

1) Normality Test

\begin{tabular}{llll}
\hline Variable & $\begin{array}{l}\text { Signific } \\
\text { ant }\end{array}$ & $\begin{array}{l}\text { Asym. } \\
\text { Sig. } \\
\text { (2taile } \\
\text { d) }\end{array}$ & $\begin{array}{l}\text { Explan } \\
\text { ation }\end{array}$ \\
\hline $\begin{array}{l}\text { Unstandar } \\
\text { dized } \\
\text { residual }\end{array}$ & 0,05 & 0,134 & Normal \\
\hline \multicolumn{4}{r}{ Table 1. Normality test } \\
\hline
\end{tabular}

Based on the table of results of the normality test data above, the Asymp value is obtained Sig (2 tailed) of 0.134 . This value is more than the value of $\alpha(0.05)$ so that it can be concluded that the data in this study are normally distributed

2) Linearity Test

\begin{tabular}{lcrc}
\hline \multicolumn{1}{c}{ Variable } & F & F table & Explanation \\
\hline $\begin{array}{l}\text { Religiosity } \\
\text { (X1) }\end{array}$ & 1.627 & 1.68 & Linear \\
\hline $\begin{array}{l}\text { Income } \\
\text { (X2) }\end{array}$ & 1.055 & 1.48 & Linear \\
\hline
\end{tabular}

Islamic $0,618 \quad 0,85$ Linear
Financial
Literacy
Table 2 . Linearity Test
Based on the table results of the
linearity test above it is known that all
variables $\mathrm{X}$ have a linear relationship with
the variable $\mathrm{Y}$.

3) Multicollinearity Test

\begin{tabular}{lrrl}
\hline Variable & Tolerance & VIF & $\begin{array}{l}\text { Explanati } \\
\text { on }\end{array}$ \\
\hline $\begin{array}{l}\text { Religiosity } \\
\text { (X1) }\end{array}$ & 0,626 & 1,598 & $\begin{array}{l}\text { There is } \\
\text { no } \\
\text { multicolli } \\
\text { nearity }\end{array}$ \\
\hline $\begin{array}{l}\text { Income } \\
\text { (X2) }\end{array}$ & 0,881 & 1,135 & $\begin{array}{l}\text { There is } \\
\text { no } \\
\text { multicolli } \\
\text { nearity }\end{array}$ \\
\hline $\begin{array}{l}\text { Islamic } \\
\text { Financial }\end{array}$ & 0,577 & 1,732 & $\begin{array}{l}\text { There is } \\
\text { no } \\
\text { Literacy }\end{array}$ \\
& & $\begin{array}{l}\text { multicolli } \\
\text { nearity }\end{array}$ \\
\hline
\end{tabular}

Table 3. Multicollinearity Test

Based on the table above, it is known that the tolerance value of all independent variables has a value of more than 0.10 and the VIF value of all independent variables has a value of less than 10.0. This means that there is no correlation between the independent variables in the regression model or that there is no multicollinearity in the regression model. 
4) Heteroscedasticity Test

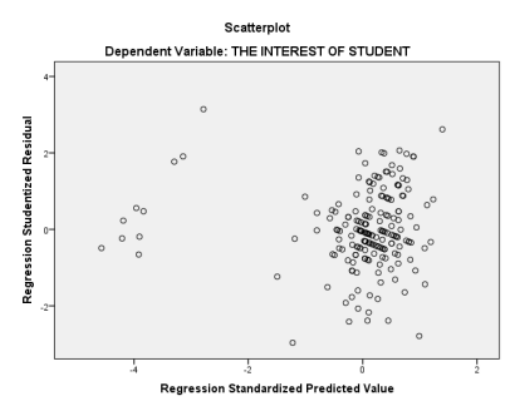

Figure 1. Heteroscedasity test

Based on the Scatterplots graph above, it can be seen that the points spread and did not form a clear pattern. So that it can be concluded that there is no heteroscedasticity

\section{Result of Hypothesis}

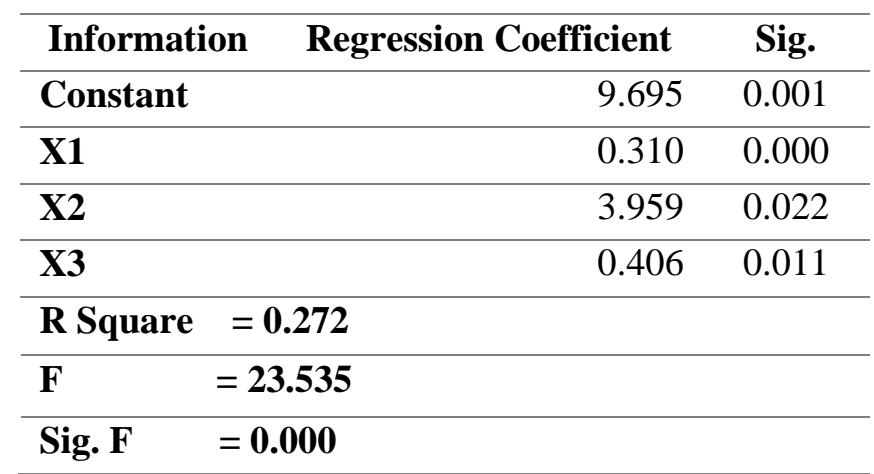

From the results of the Multiple Linear Regression test above, the value of $\mathrm{R}$ Square is 0.272 which means that as much as $27.2 \%$ Interest Students become customers in Sharia Finacial Institutions are influenced by Religiosity, the level of Income and Islamic Financial Literacy Level and as much as $72.8 \%$ are influenced by other factors. The hypothesis test equation can be written as follows:

$\mathrm{Y}=9.695+0.310 \mathrm{X} 1+3.959 \mathrm{X} 2+0.406 \mathrm{X} 3$
Based on the regression equation, it can be seen that:

1) The coefficient regression value of Religiosity is 0.310 , it can be seen that if the value of Raligiosity increase by 1 point, then the Income and Islamic Financial Literacy are considered constant, the Interest Of Student To Become Customers In Sharia Financial Institution variable will increase by 0.310 points. The significance value of the Religiosity variable has a value of 0.000 smaller than 0.05 , it can be concluded that the Religiosity variable has a positive effect on Student Interest as a Customer in Sharia Finacial Institutions, so H1 is accepted.

2) The coefficient regression value of the level of Income is 3.959, it can be seen that if the value of Income increase by 1 point, then the Religiosity and Islamic Financial Literacy are considered constant, the Interest Of Student To Become Customers In Sharia Financial Institution variable will increase by 3.959 points. The significance value of the income variable has a value of 0.022 smaller than 0.05 , it can be concluded that the income variable has a positive effect on student interest in being a customer at the Sharia Finacial Institution, so $\mathrm{H} 2$ is accepted. 
3) The coefficient regression value of Islamic Financial Literacy is 0.406 , it can be seen that if the value of Islamic Financial Literacy increase by 1 point, then the Religiosity and Income are considered constant, the Interest Of Student To Become Customers In Sharia Financial Institution variable will increase by 0.406 points. The significance value of the Financial Literacy Level variable has a value of 0.011 bigger than 0.05 , it can be concluded that the variable level of Islamic Financial Literacy has a positive effect on Student Interest as a Customer in Financial Institutions Sharia, so H3 is accepted.

4) The constant value is 9.695 , it shows that Religiosity, the level of Income and Islamic Financial Literacy are considered constant, then the Interest Of Student To Become Customers In Sharia Financial Institution value is 9.695 point. From the multiple linear regression table, it is known that the significance value has a value of 0,000 smaller than 0.05 , it can be concluded that the variables of Religiosity, the level of Income and Level of Islamic Financial Literacy simultaneously have a positive effect on Interest Of Student To Become Customers In Sharia Financial Institution, so H4 is accepted.

\section{Discussion}

Results of the first hypothesis in this research indicate that Religiosity has positive affect toward The Interest Of Student To Become Customers In Sharia Financial Institution. The results supporting to the results of Hegazy (1995), Metwally (1996), Hamid and Nordin (2001), Youseef and Kortam (2015) and Masruroh (2015). Someone who has a high level of religiosity will have a lifestyle in accordance with his religious teachings. Religiosity is not only about worship but various other aspects of life such as how to manage finances well, so that religiosity can have a positive effect on students' interest in becoming customers in sharia financial institutions.

Results of the second hypothesis in this research indicate that Income has positive affect toward The Interest Of Student To Become Customers In Sharia Financial Institution. The results supporting to the results of Masruroh (2015) and Maghfiroh (2018) who stating that Religiosity has positive affect toward The Interest Of Student To Become Customers In Sharia Financial Institution. Students have different sources of income such as money from their parent, scholarships, business, and so on. Thus, students have their own decisions to manage their finance, one of the decisions that can be made by students is to become customers in Sharia 
Finacial Institutions, so that income has a positive effect on the interest of students to become customers in Sharia Finacial Institutions

Results of the third hypothesis in this research indicate that Islamic Financial Literacy has a positive affect toward The Interest Of Student To Become Customers In Sharia Financial Institution. These results of the research are support the results of Hung et. al (2009); Glaser and Weber (2007), Jafar and Musa (2013), it found that the financial literacy will influence a person in performing a behavior.

Results of the fourth hypothesis in this research indicate that Religiosity, the level of Income, and Level of Islamic Financial Literacy simultaneously has positive affect toward The Interest Of Student To Become Customers In Sharia Financial Institution

\section{CLOSING}

\section{Conclusions}

Based on the results and discussion in the previous chapter can be concluded as follows:

1) Religiosity has a positive affect toward The Interest Of Student To Become Customers In Sharia Financial Institution. This is indicated by the significance value of $0.000(0.000<$ $0.05)$. The coefficient regression value of Religiosity is 0.310 , it can be seen that if the value of Raligiosity increase by 1 point, then the Income and Islamic Financial Literacy are considered constant, the Interest Of Student To Become Customers In Sharia Financial Institution variable will increase by 0.310 points.

2) The Level of Income has a positive affect toward The Interest Of Student To Become Customers In Sharia Financial Institution. This is indicated by the significance value of $0.022(0.022<$ 0.05). The coefficient regression value of Income is 3.959 , it can be seen that if the value of Income increase by 1 point, then the Religiosity and Islamic Financial Literacy are considered constant, the Interest Of Student To Become Customers In Sharia Financial Institution variable will increase by 3.959 points.

3) Islamic Financial Literacy has a positive affect toward The Interest Of Student To Become Customers In Sharia Financial Institution. This is indicated by the significance value of 0.011 (0.011 < $0.05)$. The coefficient regression value of Islamic Financial Literacy is 0.406 , it can be seen that if the value of Islamic Financial Literacy increase by 1 point, then the Religiosity and Income are considered constant, the Interest Of Student To Become Customers In Sharia 
Financial Institution variable will increase by 0.406 points.

4) Religiosity, The Level of Income, and Level of Islamic Financial Literacy has positive affect toward The Interest Of Student To Become Customers In Sharia Financial Institution. This is indicated by the significance value $0.000(0.000<$ $0.05)$, and R2 is 0.272 which shows that $27.20 \%$ is influenced by the three variables and $72.80 \%$ influenced by other factors not examined in this research. So it can be conclude that Religiosity, Income, and Level of Islamic Financial Literacy simultaneously positive affect toward the Interest Of Student To Become Customers In Sharia Financial Institution

\section{Suggestion}

1) For the student:

a) It is necessary to improve religiosity in economic life in order to behave according to the rules in it.

b) With income, students can use part of their income not only for consumption needs but also for savings,

c) Need to improve Islamic financial literacy so that students are aware of the existence of Sharia Finacial Institutions and participate in channeling good information about Islamic financial literacy later.

2) For Academics

Need to improve the quality of student sharia financial literacy knowledge so that one of the targets in the OJK National Financial Literacy Strategy (SNLKI) is reached

\section{REFERENCE}

Abdul Hamid, A.H., \& Mohd Nordin, N.A. (2001). A Study on Islamic Banking Education Experience

Abdul Rouf. (2011). Analisis Faktor-faktor yang Mempengaruhi Minat Masyarakat Membayar Zakat di Rumah Zakat cabang Semarang.Institut Agama Islam Negeri Walisongo Semarang.Skripsi. Semarang

Andri Soemitra. (2009) Bank dan Lembaga Keuangan Syariah. Jakarta: Kencana, pgs 36

Badan Pusat Statistik (2016). Diakses melalui http://bps.co.id pada tanggal 21 Juni 2018 pukul 10.14 WIB

Basri, M Y. (2015). Pengaruh Gender, Religiusitas, dan Sikap Love of Money pada Persepsi Etika Penggelapan Pajak Mahasiswa Akuntansi. Jurnal Ilmiah Akuntansi dan Bisnis Vol. 10, No. 1

Bley, J., \& Kuehn, K. (2004). Conventional Versus Islamic Finance: Student Knowledge and Perception

Chen, Haiyang and Volpe, Ronald P. (1998). An Analysis of Personal Financial Literacy Among College 
Students, Financial Services Review, 7(2): 107-128, ISSN: 1057-0810

Djamaluddin Ancok \& Fuat N. Suroso.(2011). Psikologi Islami. Yogyakarta: Pustaka Pelajar

Dornbusch, Rudiger dan Stanley Fischer. (1997). Makro ekonomi. Alih bahasa Julius A. Mulyadi. Jakarta: Penerbit Erlangga.

Farah margareta \& Reza Arief Pambudhi (2015). Tingkat Literasi Keuangan Pada Mahasiswa S-1 Fakultas Ekonomi. Jurnal Manajemen Dan Kewirausahaan. Vol 17, No 1.76-85.

Glock, C. Y., \& Stark, R. (1965). Religion and Society in Tension. Chicago: Rand McNally

Hegazy, I. A. (1995). An empirical comparative study between islamic and commercial banks'selection criteria in egypt. International Journal of Commerce and Management, 5(3), 46-61.

http://www.beritasatu.com/ekonomi/30671

9-nasabah-bank-syariah-1875-

persen-dari-total-konvensional.html. Diakses pada tanggal 21 Juni 2018 pukul 11.00 WIB.

Huston, S.J. (2010). Measuring financial literacy. The Journal of Consumer Affairs, 44(2), 296-316.

Huston, Sandra J. (2010). Measuring financial literacy. Journal of Consumer Affairs, 296-316

In The United Arab Emirates. International Journal of Islamic Financial Services, 5(4).

Iriantara, Yosal. (2009). Literasi Media. Bandung: Simbiosa Rekatama Media. hlm. 4
Jaffar M. A., \& Musa R. (2014). Determine of Attitude towards Islamic Financinng among Halal-Certified Micro and SMEs: A Preliminary Investigation. Social and Behavior Sciences. 30, 135-144

Jalaluddin. (2010). Psikologi Agama. Jakarta: PT Raja Grafindo Persada.

Jogiyanto,H.M. (2007). Sistem informasi keperilakuan. Yogyakarta: Erlangga

Kamus Besar Bahasa Indonesia Online (http://kbbi.web.id/minat). Diakses pada 25 Juni 2018 pukul 10.20 WIB

Kasmir. (2008). Bank dan Lembaga Keuangan lainnya. Jakarta: PT Raja Grafindo Persada, pgs. 2

Kotler, Philip \& Keller, Kevin L.(2009). Manajemen Pemasaran. Jakarta: Erlangga

Lahsasna, Ahcene. (2016). Framework of Islamic Financial Education and Literacy. Joural of Wealth Management and Financial Planning. Vol 3.

Lucas,D.B.\& Britt,S.H. (1950).Advertising Psycology and Research, New York: McGraw-Hill

Maghfiroh, Sayyidatul. (2018). Pengaruh Religiusitas, Pendapatan, dan Lingkungan Sosial Terhadap Minat Menabung di Bank Syariah pada Santri Pesantren Mahasiswi Darush Shalihat. Skripsi.Yogyakarta

Masruroh, Atik (2015). Analisis Pengaruh Tingkat Religiusitas dan Disposabel Income Terhadap Minat Menabung Mahasiswa Perbankan. Skripsi. Yogyakarta.

Matthew W. Ford \& Daniel W. Kent. (2010). Gender Differences in 
Student Financial Market Attitudes and Awareness: An Exploratory Study. Journal of Education for Business Volume 85, Issue 1

Metwally, M. (1996). Attitudes of Muslims towards Islamic banks in a dualbanking system. American Journal of Islamic Finance, 6(1), 1117.

Mohamad Azmi A. \& Anderson A. (2015). Journal of Emerging Economies and Islamic Research. Vol. 3, No. 2

Purnomo M Antara, Rosidah Musa dan Faridah Hassan. (2015). Bridging Islamic Financial Literacy and Halal Literacy: The Way Forward in Halal Ecosystem.Journal of Procedia Economics and Finance. 196 - 202

Priyatno, D. (2012). Cara Kilat Belajar Analisis Data Dengan SPSS 20. Yogyakarta: Andi Offset

Riduan \& Sunarto. (2009). Pengantar Satatistika Untuk Penelitian Pendidikan, Sosial, Komunikasi, Ekonomi dan Bisnis. Bandung: Alfabeta

Remund, D. L. (2010). Financial Literacy Explicated: The Case for a Clearer Definition in an Increasingly Complex Economy. The Journal of Consumer Affairs, Vol. 44, No. 2, pp. 276-295.

Sadono Sukirno. (1999). Pengantar Teori Makroekonomi. Jakarta: PT Raja Grafindo Persada

Sugiyono. (2015). Metode Penelitian Kuantitatif, Kualitatif, dan $R \& D$. Bandung: Alfabeta.

Sulistyo, H. (2014). Relevansi Nilai Religius dalam Mencegah Perilaku
Disfungsional Audit. Jurnal Ekonomi Manajemen dan Akuntansi. No. 36.

Syafii Antonio. (1999). Bank Syariah: dari Teori ke Praktik. Jakarta: Gema Insani Press

Trenggonowti. (2009). Metodologi Penelitian Ekonomi dan Bisnis. Yogyakarta: BPFE-Yogyakarta

Undang-undang Republik Indonesia nomor 10 tahun 1998 tentang perubahan atas undang-undang nomor 7 tahun 1992 tentang perbankan diakses melalui http://bpkp.go.id 